\title{
総説
}

\section{臼歯用コンポジットレジンの咬耗とその事前， 事後対策について}

\author{
細 田 裕 康

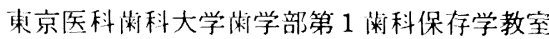

\section{In vivo Wear of Posterior Composites and Its Counterplan \\ Before or After Insertion}

\section{Hiroyasu Hosoda}

Department of Operative Dentistry, Faculty of Dentistry, Tokyo Medical and Dental University

\section{I .はじめに}

R. L. Bowen ${ }^{1)}$ によって開発されたコンボジッ トレジンは, 1964年秋に Addent 35 (3 M社) と いら製品として歯科界に初めて登場した。以来, その臨床使用は急増し, その後の材料, 技法の改 良, 改善之相俟って, この種材料の使用頻度は歯 冠色修復物の大部分を占めるよらになったといっ ても過言ではあるまい。

このように, 初めはこの種レジンは前歯の修復 を目的として計画されたものであるが，熱膨脹係 数は小さく, 圧縮強さが強大であり, その上, 実 験室における耐磨耗性試験でもアマルガムに匹敵 する性能を示したことから，アマルガム材料の代 用品としての価值が論じられるよらになった。

Phillips ら 2 4) は前歯用コンポジットレジン Adaptic を評価するため，アマルガム合金 Velvalloyと比較しながら II 級修復に用いた場合の臨 床的椮討を加之, 1 年後の成績では特に磨耗の点 で両者にほとんど差を生じなかった事実から、コ ンボジットレジシがフマルガムの代替物になりら ると報告したが，さらに臨床研究を継続し 2 年目 に入って実質的変化の現れ始めたことを，さらに
2 年後に約 5 割のレジン修復物に咬耗を認め, 3 年後には 8 揢以上に咬耗を認め, ほとんど変化の ないアマルガム修復物と大きな差のあったことを 報告している。その後, Leinfelderら多くの研究 者達5 9) も在来のコンホジットレジンを臼雪咬合 面に充塤し, その臨床経過を観察し咬耗の著明な ことを確認している。 かよらな事実から、コンホジットレジンは目蒋 咬合面には適応しないと考えられるようになった が，酸エッチング法の導入渵や接着性レジン（ボ

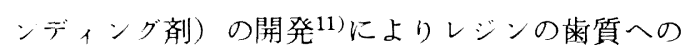
接着性が向上したこと,さらにはアマルガム水銀 による環境污染が問題化したことから、コンポジ ットレジンの臼雪部への応用の歩みが，日本にお いて特に急速になった。

近年では，臼歯修復用材料として自家重合型お よび光重合型の数種のコンポジットレジンが開 発, 市販され, 一般臨床にも徐々に用いられるよ らになった。これらの材料は耐磨耗性を向上させ る目的でフィラーの形態に修正が加兄られ，機珹 的物性が大幅に改善されてはいるが，実際的評価 はいまだ十分ではない。

本論交では，はじめに，日本で早くに開発市販 
された臼菓用コンボジットレジン 3 種を中心に， それに前歯用コンボジットレジン 1 種扮よびアマ ルガム 1 種を対照として用い, 特に咬耗について 調心，現在 2 年余を経過中なので，これまで明ら かにされたことについて記述し、コンポジットレ ジンの峧耗に関する考察を加克，さらに，起こり らるコンポジットレジンの咬耗に対する事前抢よ び北後対筑について考它てみたいと思う。

なお，論文中咬耗に関するデーターは当教宇の 堀江の研究12,13)に負うところが大きい。

\section{II . 臼歯成形修復物の咬耗状態の推移}

臼歯部の成形修復物の咬耗を観察, 検討するに あたり 2 つの場合を考光てみる必要がある。すな わち，修復物が対合雨と淔接咬合接触する場合 と，咬合接触しない場合である。

\section{1. 対合接触のない場合の咬耗}

前雨用コンボジットレジンであるクリアフィル Fを臼雨に充填した場合にみられた咬耗の推移は 网1のごとくである。年月の経過とともに進行し
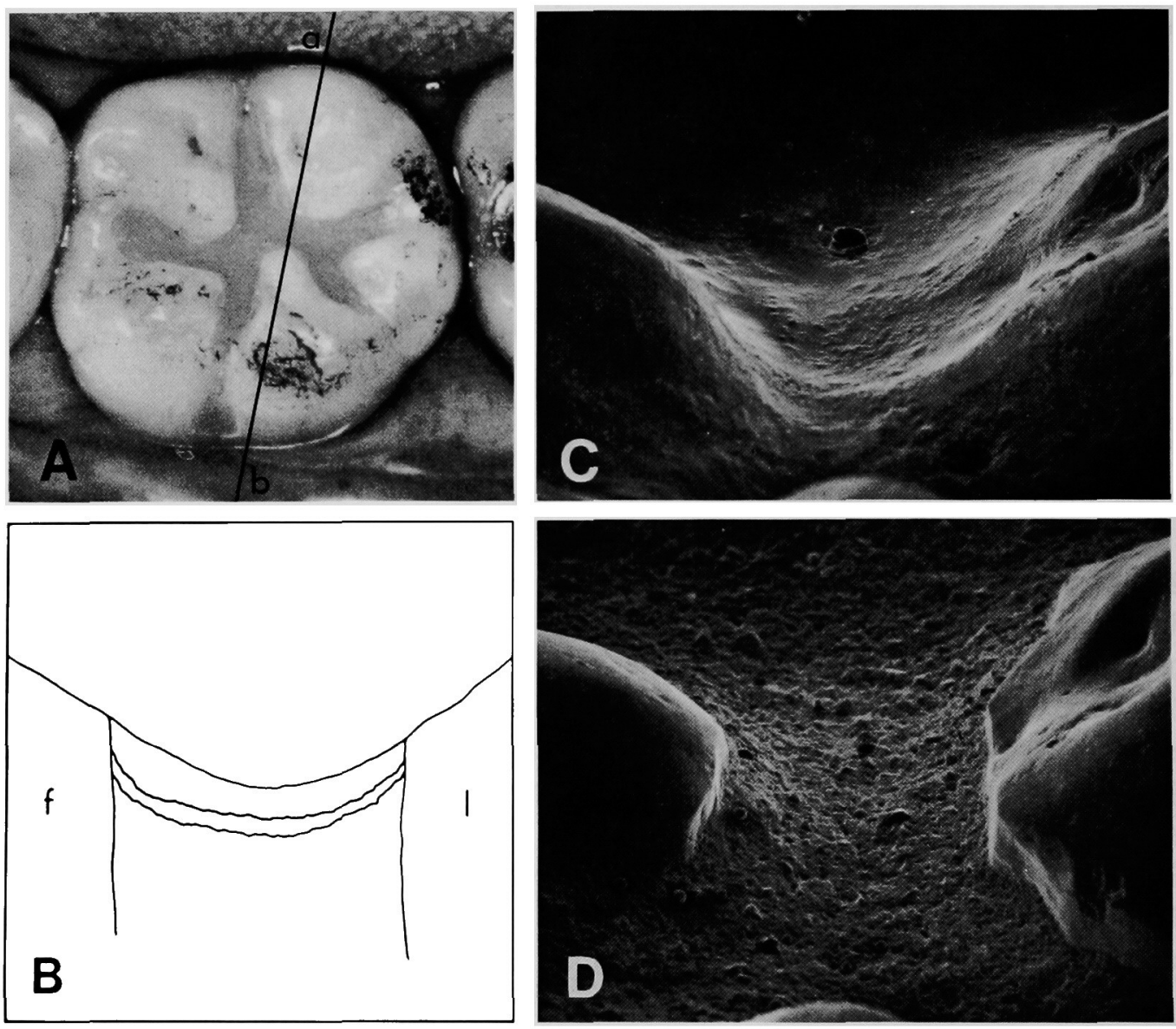

図1 クリアフィルFの咬耗の 1 症例 : $\overline{6}$ （咬合接触なし）

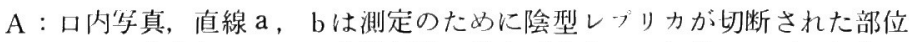

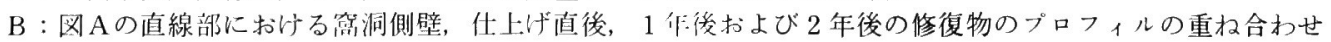
像. f : 頓側 I：舌側

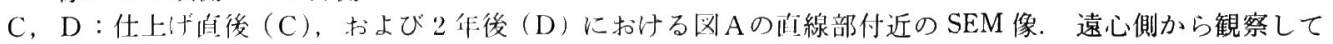
いる 
た咬耗のブロフィル(図 1-B)を无ると, 修復 1 年後に明らかに咬耗が認められ，その後の 1 年間 には前 1 年ほとではないが若干咬耗が進んでい た。その状態は Leinfelder ら ${ }^{5,14)}$ が述べているよ らに, 修復物周辺にディッチング(泟掘机)は起こ らず，修復物全面に広く材料の消失が起こり，它 の消耗のパターンが丁度 “穴のあいた円筒谷器中 に入机た水面の下り方”に近似している。また, SEM 像（図1-C，D）によりレジンの表面性状を みると，修復直後には滑沢であったものが， 2 年
後には大きなフィラーが突出し，粗造面を!りて いた。

臼蔽用コンホジットレジンであるクリアフィル ポステリアを用いた場合には，前雨用のクリアフ ィル F と違って，肉眼的観察では 1 年後, 2 年後 でも，修復值後の状態とあまり変化がないように 又。しかしながら，咬耗のプロフィル(図2B）をみると年とともにわずかではあるが層状に 消耗が進んでいくのがわかる。その消耗の程度は 前歯用レジンよりはるかに低い。このことは本材
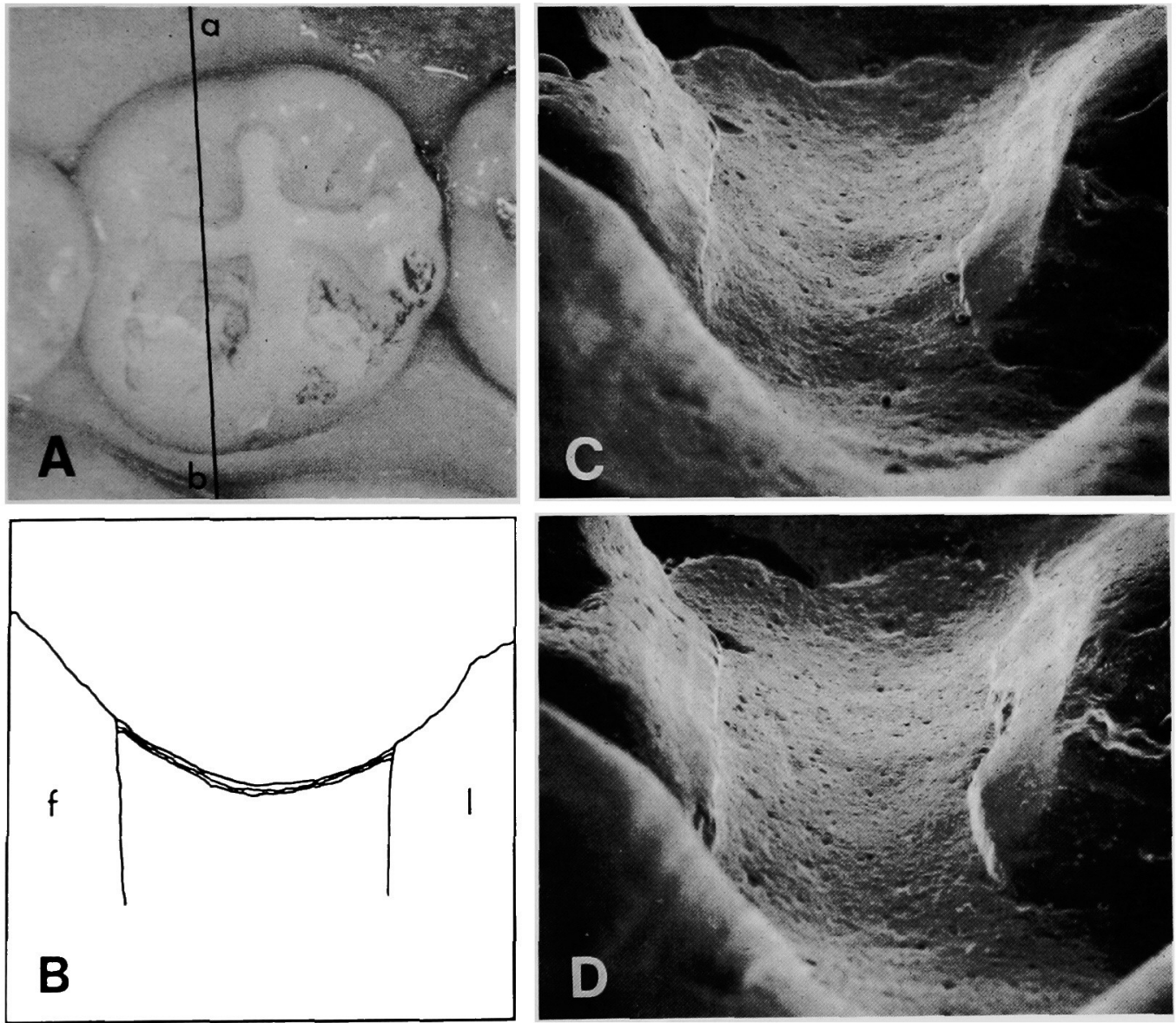

訤 2 クリアフィル・ホステリアの咬耗の 1 症例 : $\sqrt{6}$ （胶合接触なし）

$\mathrm{A}$ ：口内写真, 直線 $\mathrm{a}, \mathrm{b}$ は測定のために㓌型レつリカが切断された部位

$\mathrm{B}$ : 図Aの直線部における窩洞側壁, 仕上げ直後, 1 年後および2年後の修復物のプロフィルの重权合わせ 像. $\mathrm{f}$ : 煩側 1 : 舌側

C, D : 仕上げ直後 (C)，および 2 年後（D）における図Aの直線部付近の SEM 像. 遠心側から観察して いる 
料がF歯修復材料として十分な耐用性があること を示している。一方，その 2 年後の咬耗 SEM 像 （図 2-D）をみると、レジン表面の起伏はクリア フィル F と比べはるかに平滑で, 咬耗よりも辺縁 の小破折が著明になっているのがわかる。

脱アマルガムを指向して開発された窒化ケイ素

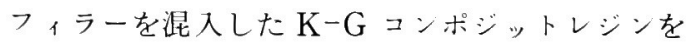
用いてみると, 肉眼でみる限り, 修復 1 年後でも 2 年後でもほとんど変化がみられなかった。しか し, 咬耗状態のプロフィル（図 3-B）をみるとク
リアフィルボステリアより若下軽度であるが，機 能咬頭側の斜面の咬耗が顕著であった。そのレジ ン面は図 $3, \mathrm{CD}$ にみらるよらに 2 年後になる と粗さが增してくるようである。

且雨用 MFR (超微粒子配合レジン)タイブのミ クロジャーを用いた場合には，臨床的に年月とと もに変色が進んでいったが，咬耗はほとんど観察 されなかった。修復物表面のプロフィルの変化 （図 4-B）をみると, 修復物辺縁に若干の小久陌 が認められる他は，咬耗は全般的に極めてわずか
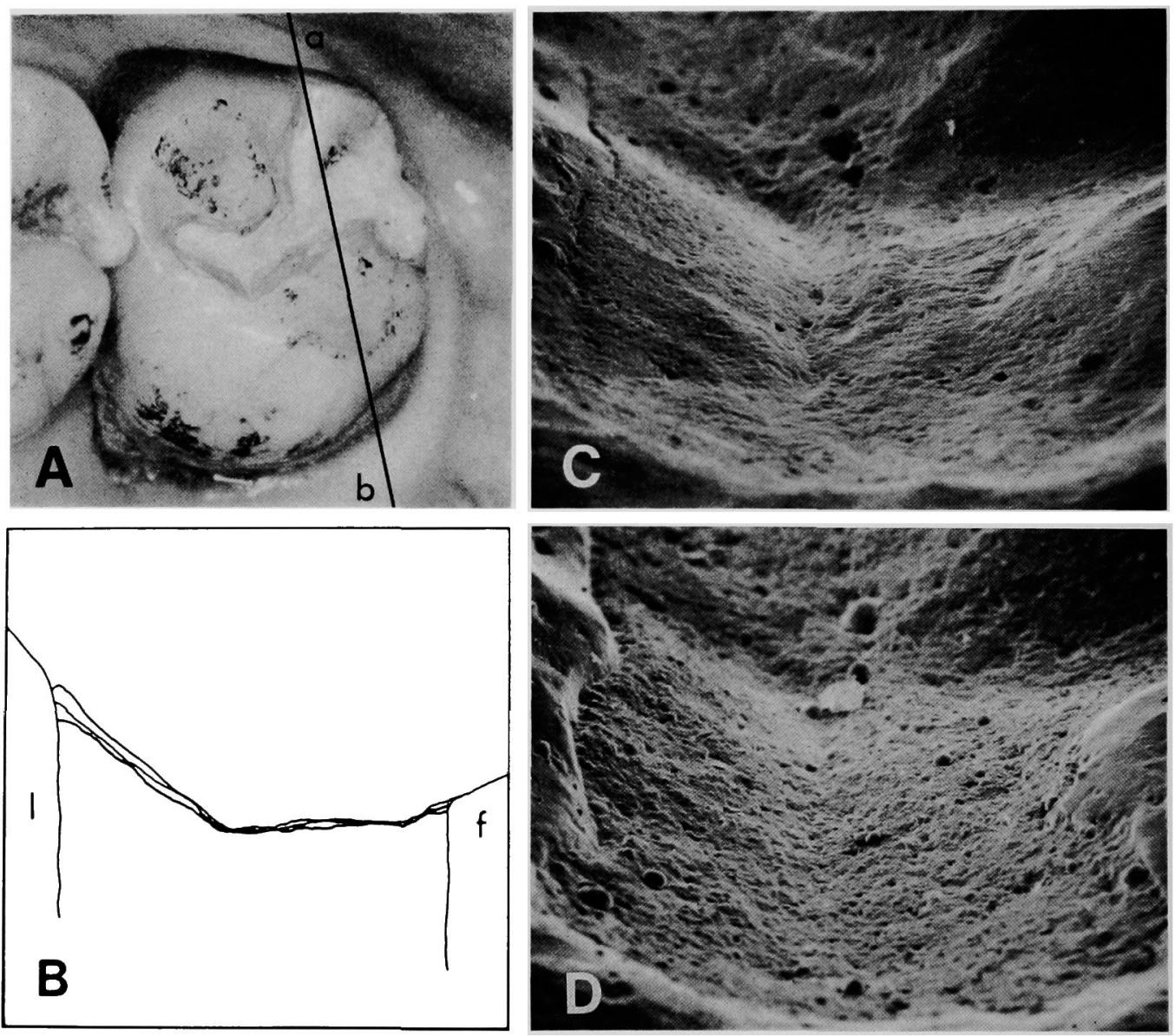

図 $3 \quad \mathrm{~K}-\mathrm{G}$ コンポジットレジンの岎耗の 1 症例 $: \mid 7$ (咬合接触なし)

$\mathrm{A} ：$ 口内写真, 通線 $\mathrm{a}, \mathrm{b}$ は測定のたのに㓌型レンリカが奵断された部位

$\mathrm{B}$ ：図 $\mathrm{A}$ の直線部にお汁る窝洞側壁，仕上げ直後，1年後および 2 作後の修復物のプロフィルの重权合わせ 像. f : 頼側 I : 舌側

C, D：仕上げ直後（C)，および2作後（D）における図Aの直線部付近の SEM 像. 遠心側から観察して いる 
であることがわかる。SEM 像(図 4-C，D）に より修復物表面を観察すると表面性状は全般に年 月を経ても滑沢で, 咬耗は認められないが辺縁部 全体に亘り小破折の出現しているのがわかる。

一方，加銅アマルガムであるスフェリカルDを 用いた場合は，肉眼的には綺醌に研磨されたア、 ルガム修復物が 1 年後には空りを带び，その辺緣 部に小破折が観然されたが，2年後に至るも咬耗 は認められなかった。これを修復物のプロフィル （図 5-B）によりみてみると，辺縁部の変化以外
には咬耗は皆無とみなしてよいであろら。その表 面性状（図 5-C，D）も滑沢であり，2年後でも お打む权修復直後の状態を保っていた。

\section{2. 対合接触のある場合}

それでは修復物が対合雨と峧合接触する場合に はどのような咬耗を示すであろらか。臼雨用コン ホジットレジン2種とアマルガムのそ机ど机につ いて観察してみよ5。

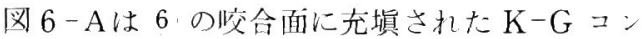
ホジットレジン修復物の口内写真である。斜走隆
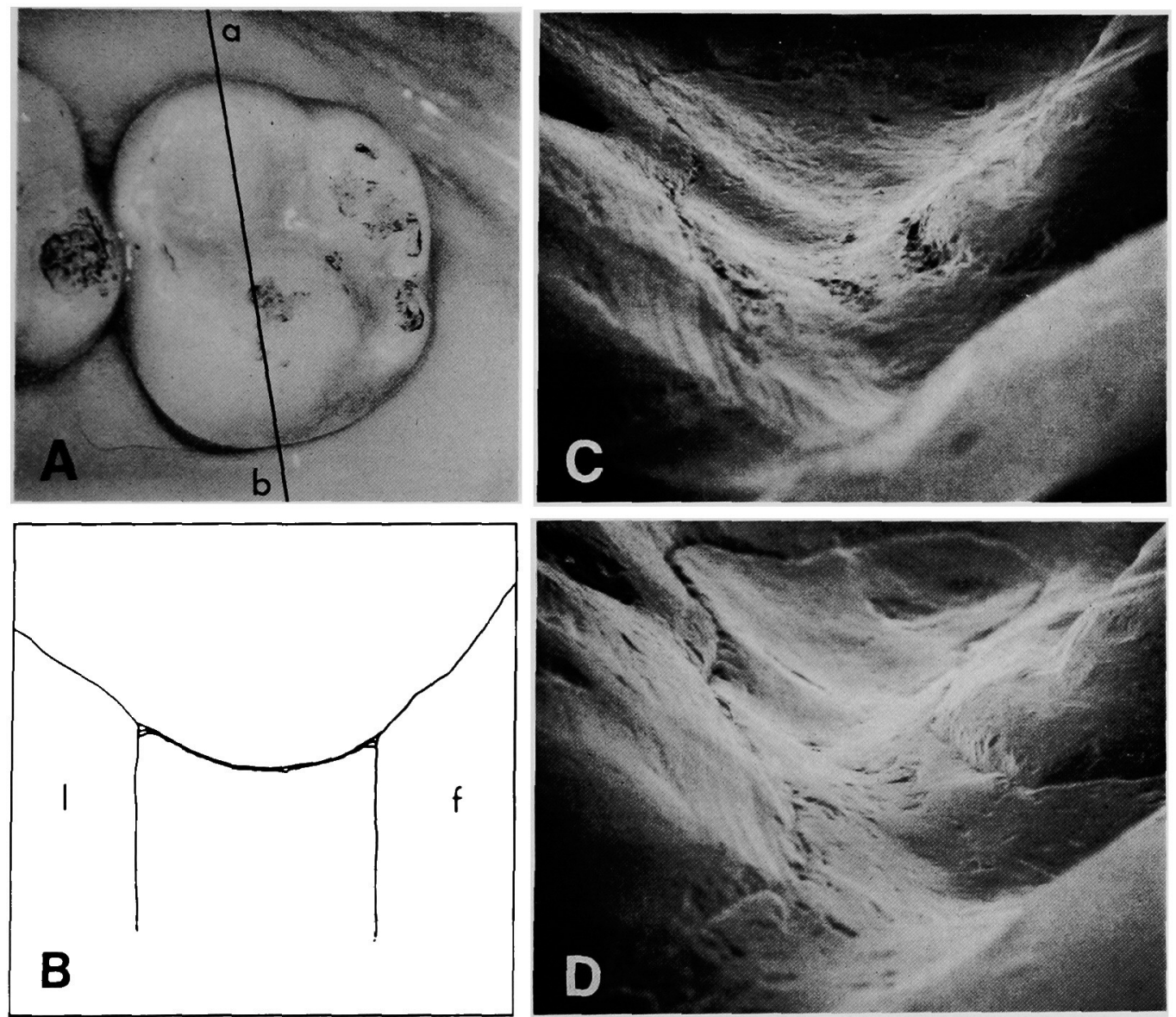

図 4 ミクロジャ一の晈耗の 1 症例： $\mid 7$ (咬合接触なし)

$\mathrm{A}$ ：口内写真, 直線 $\mathrm{a}, \mathrm{b}$ は測定のために陰型レプリカが切断された部位

B：図Aの直線部に打ける窩洞側壁, 仕上げ直後, 1 年後扰よび 2 年後の修復物のフロフィルの重权合わせ 像. $\mathrm{f}$ : 煩側 1 : 舌側

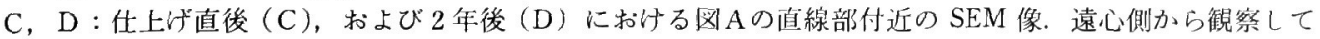
いる 
線を越えて修後した個所が対合接触しているの で，その部分を含及周辺を肉眼的に観察したが, 1 年半経過しても, 修復直後の状態と比べてほと んど変化がみられなかった。対合接触部の咬耗の プロフィル（図6-B）を无ると，強く接触してい る煩側部に初期の段階でわずかな咬耗を示すが, 1 年半後でもあまり咬耗が進んでいないのがわか る。穴の部の SEM 像（図 6-C，D）をみても， 窩縁部や表面形状に顕著な変化がスられないの で，本材料の耐咬耗性の優秀なことが同える。
图 7-Aは 7|の咬合面, 煩面, 遠心面に充媜し た MFR レジンーミクロジャー修復物の口内写真 である。この修復物を経時的に肉眼観察したとこ ろでは，年とともに咬合面煩面移行部に亀裂が発 生拡大し，頓侧辺縁部，遠心煩側部には褐線が生 じ，色調も褐色を带び，劣化の傾向をたどってい た。また，対合歯と接触していた遠心寄りの舌側 辺縁には小破片がみられ，死状を呈していた。こ の対合部分の変化をブロフィル（図 7-B）で観察 すると, 初めの 1 年間に深くえぐられた大きな欠
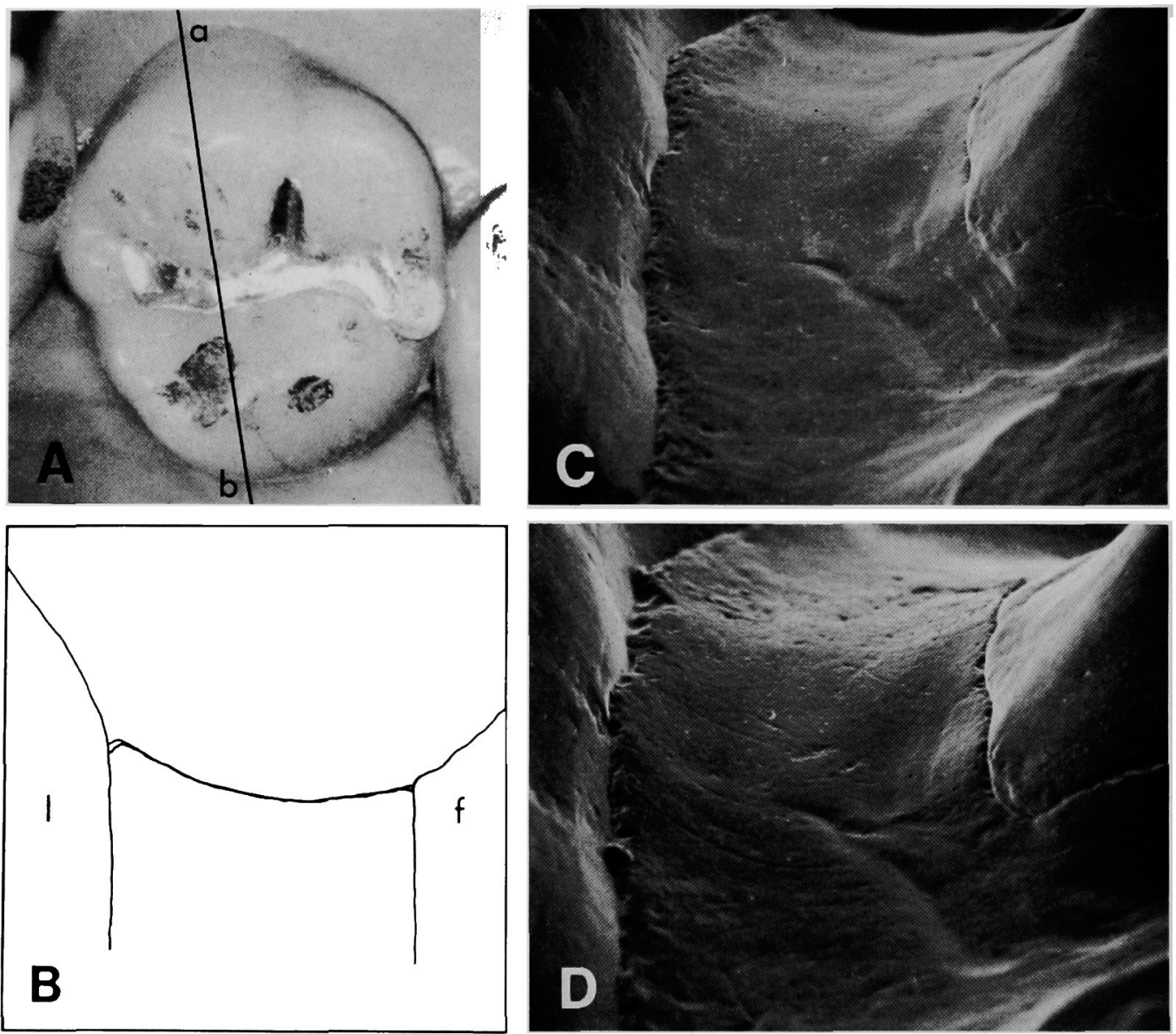

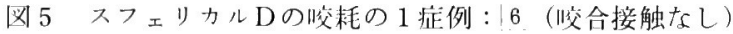

A：口内写真, 直線 $\mathrm{a}, \mathrm{b}$ は测定のために陰型レプリカが切断された部位

$\mathrm{B}$ ：汹 $\mathrm{A}$ の直線部における嵤润側壁，仕上げ直後， 1 年後および 2 年後の修復物のプロフィルの重权合わせ 像. $\mathrm{f}$ : 頓側 1 : 舌側

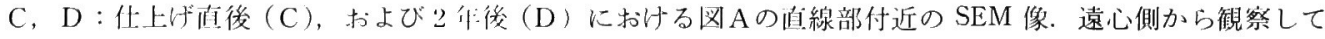
いる 
損を生じ，その後徐々にその久損は進行应大して いくのがわかる。さらに, その部の SEM 像（図 7-C，D）で欠損状態を観察すると，1年半後に はバーで掘り込んだよらな像を示し，咬合接触し ない場合の MFR とは全く違った様相を示した。

図 8 は， 7 の咬合面に充填さ扎た加銅了マル力 ムのスフェリカル $\mathrm{D}$ 修復物の口内写真である。肉 眼観祭では, 修復物は年とともに量りを带び, 辺 縁部の過剩溢出部には小破折を生じていた。さら に, 斜走隆線部の咬合接触部位には 1 年後に点状
のへこみが現れ，それが 1 年半後には少し拡大 していた。この部分をブロフィル（図 8-B）によ って観察すると, 中央部が修復直後の修復物表面 より少しへこんで找り，経洔的に媣くなっていく のが確認された。咬合面の全体的な咬耗量は極め てわずかであるが，辺縁部の小破折は避けがたい ものとなっている。さらに, SEM 像 (図8-C, D）によりその変化像を歹ると以上の所見が一層 明白である。

以上の臨床成繢にみられたように,アマルガム
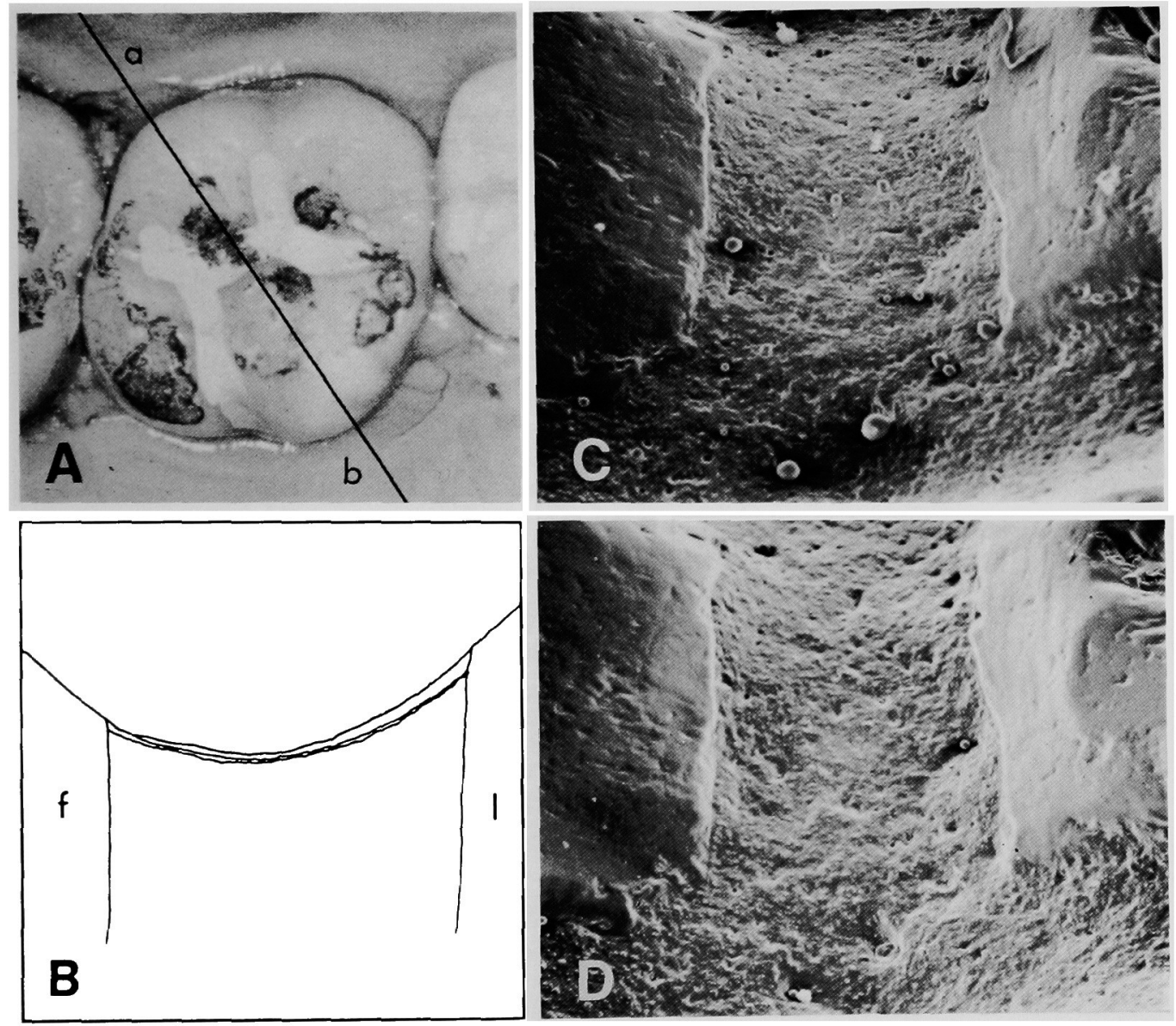

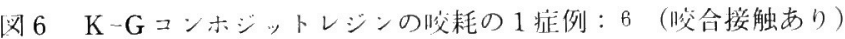

$\mathrm{A}$ ：口内宇真, 直線 $\mathrm{a}, \mathrm{b}$ は測定のために陰型レフリカが切断された部位

$\mathrm{B}$ ：図 Aの直線部における简洞側壁，仕上げ直後， 1 年後および 1 年半後の修復物のプロフィルの重权合わ 世像. f : 頼側 I：舌側

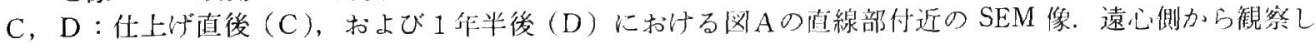
ている 
材料は咬柜に溻しては極めて安定した材料であ り、コンホジットレジンは直接的にも間接的にも 咬合により消耗し，その程度が材料によって大き な差異のあることが理解されたであろら。

\section{III. 各種修復物の咬耗量}

立 1 扣よび図 9 にみられるよらに，対合接触の ない各種修復物の 1 年後の平均咬耗量を比較して みると，前米修復用のクリアフィルFによる修復 物の咬耗量に比べ，クリアフィルホステリア扰よ

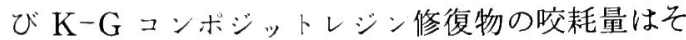
れぞれ前者の $1 / 2.5$ および $1 / 3$ で，明らかに耐磨 耗性の改善されていることがわかる。

また，各種修復物が経時的にどのような咬耗量 を示したかをみてみると,クリアフィルFでは修 復後 2 年経過すると $70 \mu \mathrm{m}$ 前後に達するが，この 咬耗量の大部分は初期の 6 ～12力月の間に出現 し, 以後 6 力月ごとの量は減少する傾向にあっ た。これは修復物がある程度咬耗すると対合雨間 に隙間ができ，修復物に加わる圧が緩和されたた
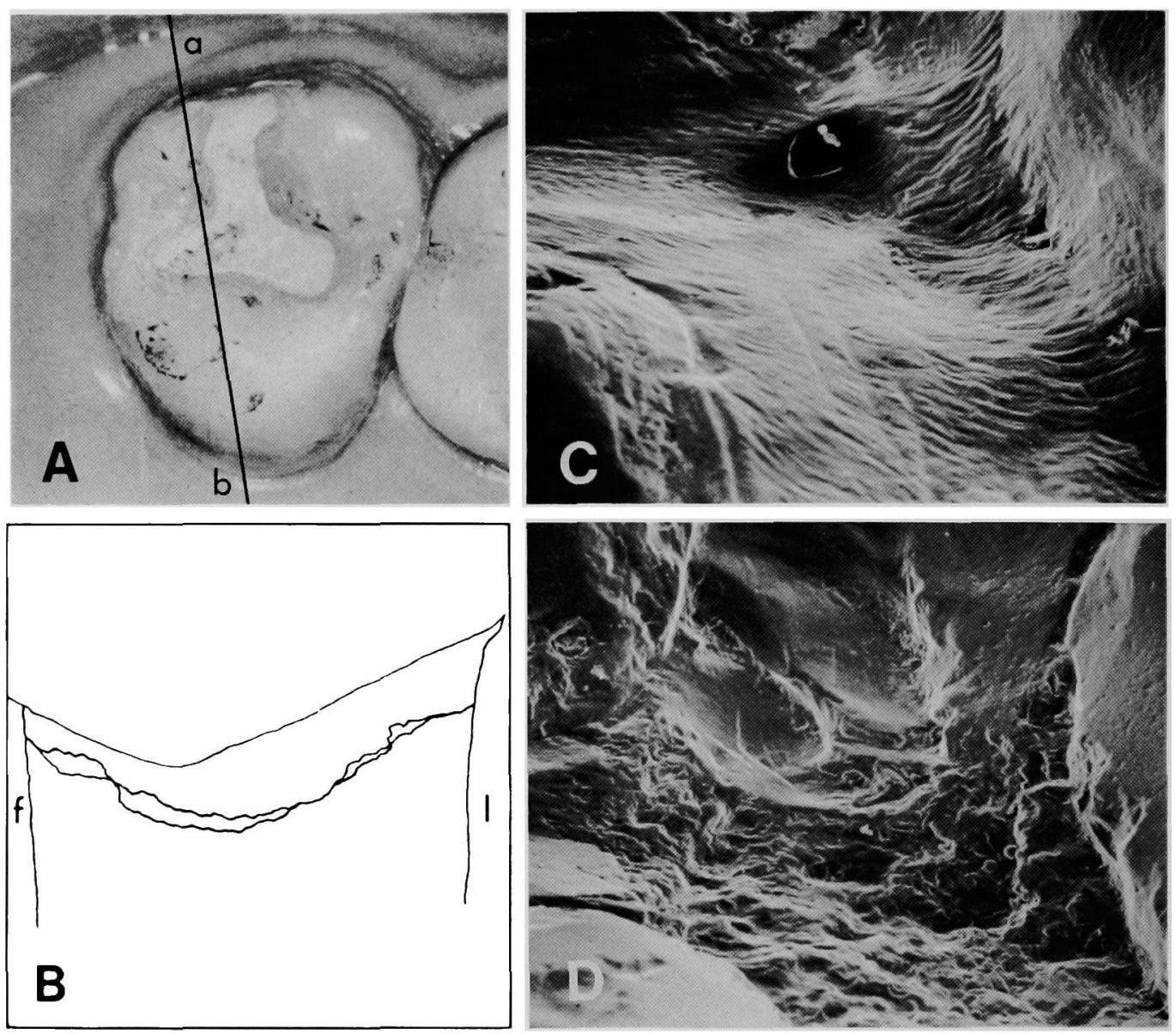

図 7 ミクロジャ一の咬耗の 1 症例： $7 \mid$ （咬合接触あり）

$\mathrm{A}$ ：口内写真, 直線 $\mathrm{a}, \mathrm{b}$ は測定のために陰型レフリカが切断された部位

$\mathrm{B}$ ：図 $\mathrm{A}$ の直線部における简洞側壁, 仕上げ直後, 1 年後および 1 年半後の修復物のプロフィルの重权合わ 世像. $\mathrm{f}$ : 煩側 1 : 舌側

C, D : 仕上け直後 (C), および 1 年半後（D）における戍Aの直線部付近の SEM 像. 遠心側から観察し ている 
めと考えられる。一方，臼歯修復用のクリアフィ ルポステリアや $\mathrm{K}-\mathrm{G}$ コンポジットでは初めの 6 カ月間には若干大きな咬耗を示すが，その後の咬 耗量は少なく，2 年後では $30 \mu \mathrm{m}$ に達していた。

臼歯用 MFR レジンのミクロジャ一は他のコン ボジットレジンに比べ、はるかに少ない咬耗量を 示し、アマルガムの咬耗に近似していた。しかし ながら、これは咬合のストレスを直接受けない場 合であって、ひとたび対合接触下に置かれると明 白な材質的欠陷を暴露し，MFRレジンの臼歯適
用には疑問が残る。

実際に，修復物がどの程度咬耗したならは臨床 上問題になるのか推測の域を出ないが，㐘牙の生 理的ないし機能的咬耗とは買なり，修復物のみが 咬耗すれば，その形態变化に伴ら咀嚼機能の低下 および食物の局所的圧入脱出による画牙への負担 過重が当然起こり，歯牙動摇の誘因となることは 十分考えられる。

したがって、臨床的に修復物表面と雨面との間 に目視しらる段差が現れると問題になる。経験的
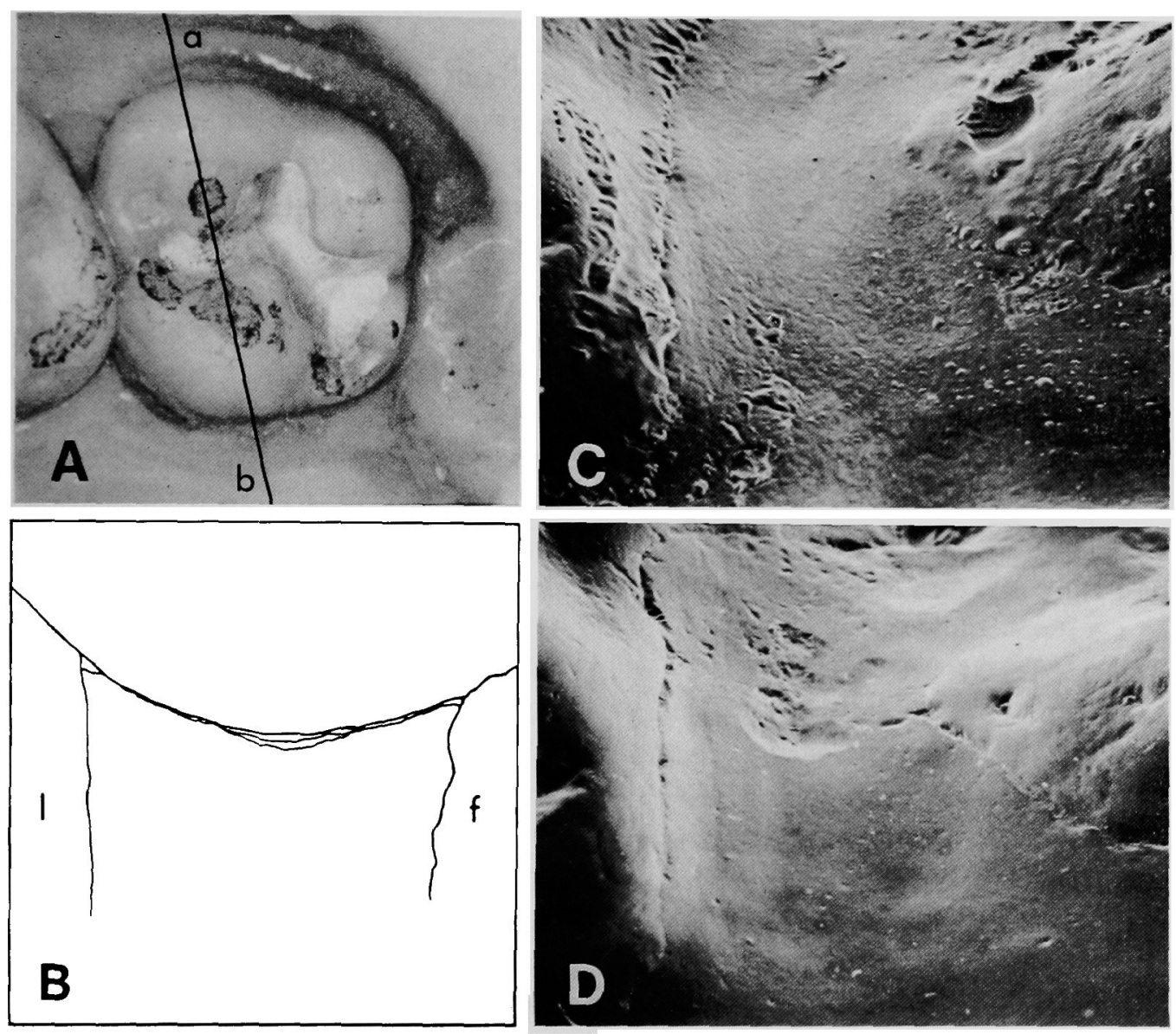

図 8 スフェリカルDの峪耗の 1 症例：７（焧合接触市り)

$\mathrm{A}$ ：口内写真, 直線 $\mathrm{a}, \mathrm{b}$ は测定のために陰型レプリカが切断された部位

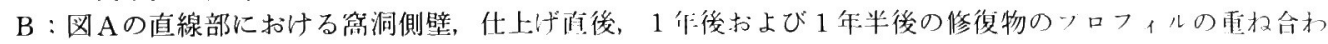
世像. f : 煩側 I：舌側

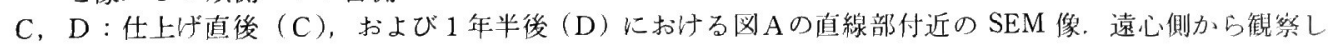
ている 
表 1 各種修缏物の咬耗量の経時的变化

\begin{tabular}{|c|c|c|c|c|}
\hline 修復材料 & 6 力月 & 12 カ月 & 18 カ月 & 24 カ月 \\
\hline クリフフィルF & $23(0.58)$ & $40(1)$ & $55(1.35)$ & $68(1.68)$ \\
\hline クリフフィルポステリフ & $9(0.59)$ & $16(1)$ & $23(1.41)$ & $26(1.65)$ \\
\hline $\mathrm{K}-\mathrm{G}$ コンボシット & $8(0.60)$ & $13(1)$ & $18(1.40)$ & $25(1.97)$ \\
\hline ミクロジャー & $2(0.53)$ & $4(1)$ & $6(1.44)$ & $8(1.96)$ \\
\hline スフェリカルーD & $1(0.58)$ & $2(1)$ & $2(1.25)$ & $2(1.37)$ \\
\hline
\end{tabular}

（）内は，1 年後の咬耗量に対する各時期の咬耗量の割合

(単位 : $\mu \mathrm{m}$ )

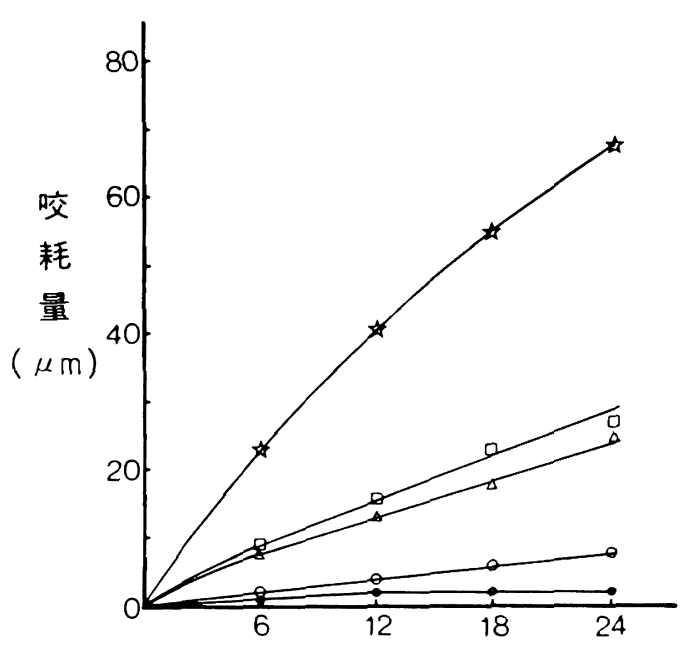

経過月数

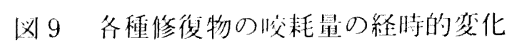
证：クリアフィルF $\square:$ クリアフィル・ホステリ

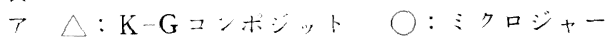

○：スフェリカルD

に肉腿で段差として明確に認知しらる量は50〜60 $\mu \mathrm{m}$ である。現用の日柬修復用コンボジットレジ

ン( MFR を除く)が修復 2 年以降もさらに咬耗し たとしても，艾耗量のデーターから推測して，5 年以降になって臨床的にどらやら段差を確認でき る状態になると思われる。

しかしながら, 今後, レジン材料, 重合法, 塤 悲法等の開発，改良によって，さらに耐咬耗性の 優れた修復物が得られることは確実である。

\section{IV.コンポジットレジンの咬耗メカニズム}

口内でヌられる従来のシリカフィラー入りコン ホジットレジンの咬耗は、マトリックスレジンが 徐々に磨耗し，やがては支持を失ったフィラーが 脱落するといら現象の繰り返しである。これらの 咬耗面の性状および均一な段階的な消耗の事実か ら推察すると，このよらな咬耗現象は主として食 物が圧維されながら擦過していくことにより起こ ると考光られる。一方, 口内の MFRレジン修復 物は特に対合接触のない場合にははるかに優れた 耐咬耗性を示していた。

しかしながら、兒験室では従来型コンポジット レジンはフブレシフ磨耗に対し強い抵抗性を示す 材料で，磨耗材を用いたさまざまなアブレシブ磨 耗試験によって，アマルガムと同程度，あるいは てれ以上の耐磨耗性を示すことが確認されてい $ろ^{2,15,16)}$ 。一方，MFRレジンは練り霜磨きなど の歯磨き剂による歯ブラシ磨耗によって, 従来型 レジンより激しく磨耗してしまうことが多くの研 究者によって確認されている年〜19)。

このよらに, 口内における咬耗と実験室におけ る成績とは全く相反する傾向を示している。この 事実をどら解釈すべきであろらか。ここではっき り言及できることは，文明人の口内の咬耗現象は 狭義のアブレシブ磨耗の要素はほとんど関与して いないといらことである。

それでは，従来型のコンポジットレジンに対し て大きな磨耗作用を及ぽし，MFR 型レジンに対 
しては磨耗作用がわずかな食物の構成要素を考兄 てみると，食物中に存在する線維以外の要素は思 いあたらない。この食物線維が媒体となり，咀嚼 作用により咬耗を惹き起こすと考えた方が妥当で あろう。

すなわち, 従来型コンポジットレジン修復物の 咬耗には，その表面に時間の経過とともに発現す る脆弱な層が大きく関与していると考えられ，こ の弱められた層が，咬合に伴ら食物線維の䀜摩作 用によって咬耗していくものと思われる。

この脆弱層ができる要因としては，フィラーと マトリックスレジンとの間の結合が劣化したり， 破壞されたりすることが挙げられる。口内の水の 存在は表層の、トリックスレジンを膨潤させるば かりでなく，その表面から種々の物質が溶出した り、フィラーとレジンとの結合を弱めたりする。 さらに, 咀嚼により修復物の表面が “疲れ”を起 こすことも十分考えられる。この場合，硬いフィ ラーは応力の集中体として働き, マトリックスレ ジンとの結合が破買されるが，そのレジンが脆い とその破壊はいっそら進行する。さらに, 冷た い, 熱い飲食物の摂取も,フィラーとレジンの結 合を緩める因子となる。

また，二剤練和型のレジンを用いた修復物には ミクロな気孔や歪みなどの欠陷を内在しているこ とを忘れてはならない。修復物にある限界以上の 応力が加わると, これらの欠陥から微小亀裂が生 長する可能性がある。当然のことながら, 修復物 が対合歯と咬合接触する場合には接触する部位の “表面疲れ”がいっそら強く現れることはいらま でもない。

臼歯用コンポジットレジンが前霜用のものに比 べて，優れた耐咬耗性を示しているのは，第 1 に, フィラーの径が全般に小さくなり，したがっ て応力の集中も少なくなり, 微小龟裂の発生の機 会が減少したためと考えられる。第 2 にはフィラ 一量の増加とマトリックスレジンの減少が挙げら れる。第 3 にはフィラーとマトリックスレジンの 結合の強化とマトリックスレジンの改善等が考光 られる。
一方， MFR レジンの場合には，フィラーがあ まりにも小さいために，いわゆる複合体特有の代 均質性に欠け，フィラー自体が応力集中体になる ことはないので，従来型レジンに比べて，“表面 疲れ”が顕著に現れなかったのではないかと推測 している。それゆ六，食物線維を媒介とする磨耗 に抵抗し，高い耐咬耗性を示したものと考えられ る。しかしながら，直接対合歯と接触した場合に は全く逆で，MFRレジンは激しい咬耗と破壊を 示した。われわれの基礎実験, 臨床試験からも, また，Lambrechts ら $5^{20)}$ も指摘しているように MFR レジンは衝撃に対する抵抗性が低いことは 明白である。

以上のことから，口内のコンポジットレジン姣 耗のメカニズムには咀嚼圧の反復作用と食物中の 線維による掅摩作用の両者が大きく関与している と考えてよいであるら。

\section{V.コンポジットレジンの咬耗対策}

臼歯修復用レジンが適用されてから現在まで， まだ短い期間であるが，適切に取り扱いさえすれ ば, 歯髄反応, 咬合痛, 2 次糔蝕など回避でき, 臨床上大きな事故は現れていない。

しかしながら，咬耗はもちろんのこと咬耗に関 連する修復物の表面形状の経時的変化は不可避な ものである。たとえば，図10にみられるように， レジン修復物と䈑壁との境界に清状に掘られた状 態が観察されたり，また，その境界またはレジン 内部に微小亀裂が発生したりしている。

このよらなことができるだけ起きないような事 前対策を講じることは今後ますます重要なことと なってくる。また，第 2 の対策として，咬耗が生 じた場合の事後対策についても考えておか权ばな らない。

\section{1. 咬耗事前対策}

1）コンポジットレジンの選択

フィラー粒子が微細化し, しかもフィラー混入 量の多いレジンが総合して優れた耐咬磨耗性を示

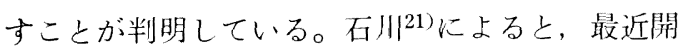
発された可視光線重合臼齿用レジンのなかには著 

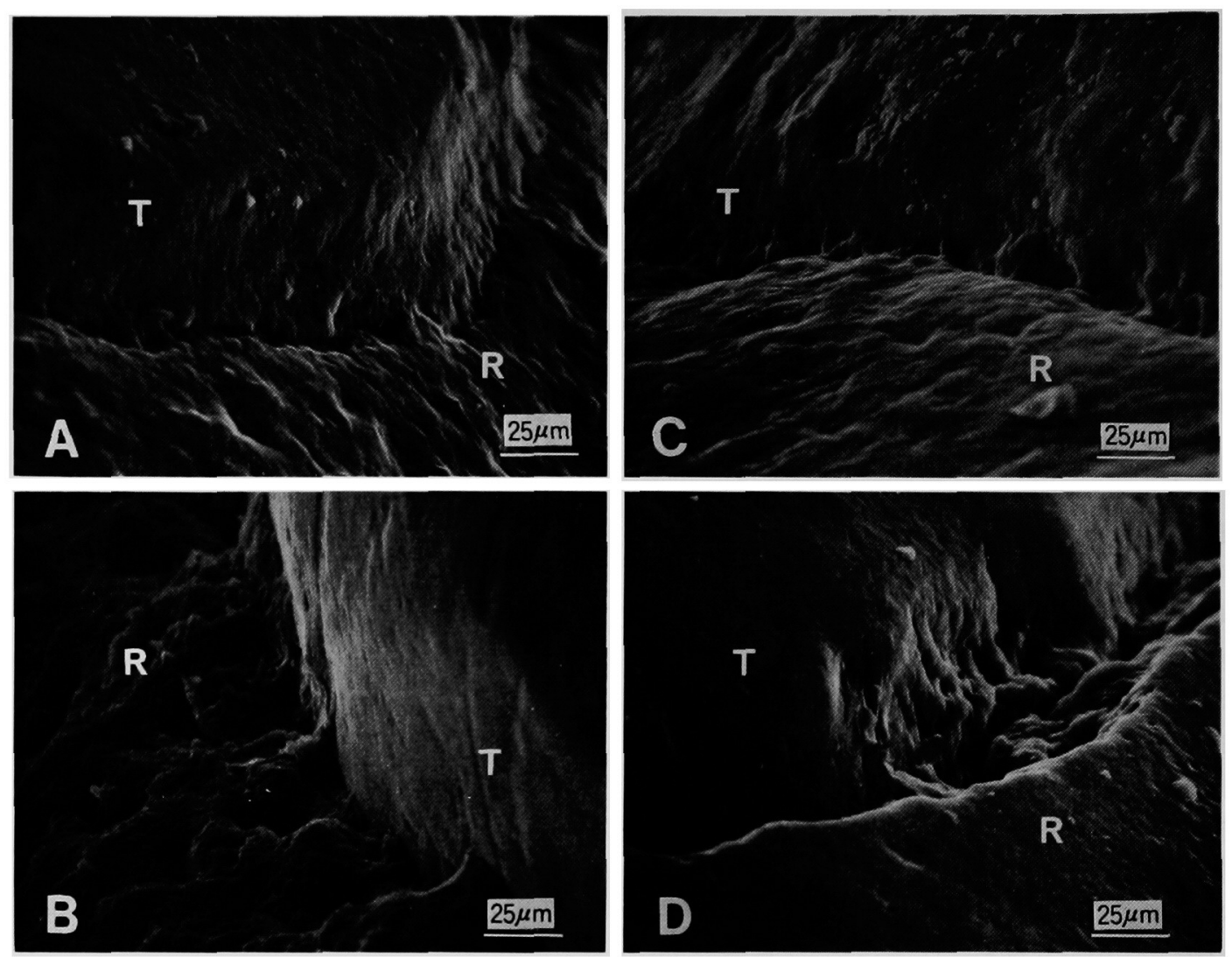

図10 2 年経過後の各種修復物の辺縁部の状態

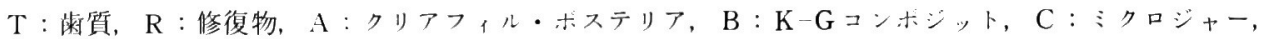
$\mathrm{D}:$ : スェリカル D

者らが用いた臼㮽用レジンよりもフィラー含有量 が重量, 容積\%ともに高く, 重合収縮率もマトり ックスレジンを变えているため従来型のものの約 1/2〜1/3に減少しているとのことである。このよ らなレジンを用い扎ば，より良好な臨床成果が期 待されるであろら。

2) 無気池練和充填法の採用

前述した可視光線重合レジンはペースト状レジ ンを简洞に填寒し，光を照射し硬化させるだけな ので、ヘースト状レジンにかなりのフィラーを混 入でき，硬化したレジンには気泡もないので，耐 咬耗性が向上することは十分予測される。

在来のヘースト・ヘーース型レジンはペースト 両者を混和しやすい稠度にするため,フィラーを
十分に混合できず，また，多数のミクロな気泡が 封入されてしまう。このミクロな気泡は耐咬耗性 の弱点になっていることは前述したとおりであ る。

そこで, 細田・山田は無気泡練和充塤法22)を案 出した。本法を採用すれば,フィラー量の多い硬 いベーストでも，気泡なく容易に練和できる。し たがって, 本法により, ペースト・ペーストタイ プのレジンに改良を加えたものを使用すれば光重 合レジンと同程度の性能をもった修復物が期待さ れるであろう。

\section{3）窩洞形態}

図10にみられたよらに，長時日を経るとレジン 修復物辺縁にディッチングが起きる。このような 


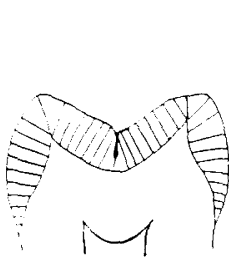

A

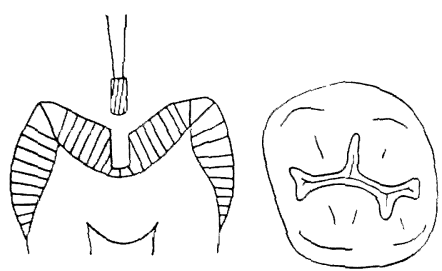

C

B

I 級エナメル質窩洞の形成

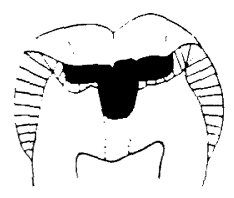

A

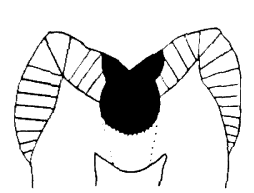

B

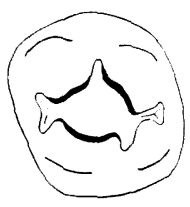

C
図12 I 級エナメルー象牙質複合简洞の形成

現象を極力回避するためには特別の考虑を要す る。図11のように, 咬合に関与しない細いI級窩 洞では，エナメル小柱外端が切られているので, この部にはレジンタグの形成が促進され，接着も 良好となる。それゆえ, レジン辺縁が多少薄くな っても問題はない。

しかしながら，図12のように，䠛蝕の搪大に伴 い䆚洞外形も大きくなり，䈑縁が対合歯と接触す るような場合には、レジン辺縁を厚くし，かつ, レジンとエナメル質との接着力を強化するため に, 著者 ${ }^{23,24)}$ の推奖するラウンドベベル(図13)を 付与すると辺縁漏洩の防止も確実となり予後は良 好である。

\section{2. 咬耗の事後対策}

田曾修復用コンポジットレジンはさらに改良す べき余地を残しているとはいえ，アマルガム材料 を用いることは時代への逆行である。歯質と十分 に接着し, 臨床的性能の良いレジン材料の使用を 指向して今後も歩みを進めていくべきと考古る。 したがって，現用レジンがいま少し，耐磨耗性が 劣り，咬耗を生じることがあっても，いたずらに 手を拱いてその使用に批判的でいるより，むし ろ,さらにより良い材料の出現を望みながら, 起

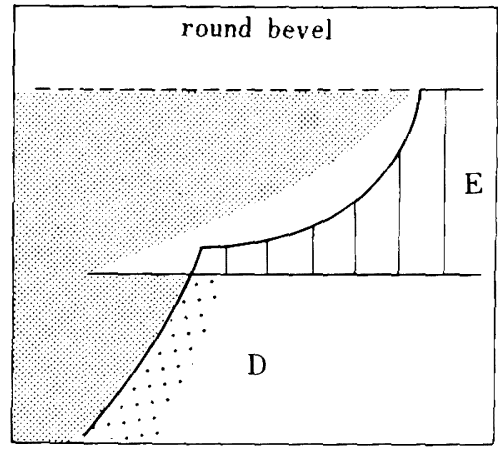

図13

きつつある欠宿の対策に思いを馳せるべきである 5。

このよらな観点から，咬耗部の補修対策を考え てみよう。

図14は人工睡液に従来型レジンを 3 力月間浸清 したのちに，新しいレジンを追加した場合のレジ ンの接着力の成綪 ${ }^{25)}$ である。水洗乾燥しただけの 面に対する追加レジンの接着強さは極めて低く, その面をブラシで清掃しても全く効果がない。し かし，カーバイドバーで表層を削り新鮮面を出す と一挙に強さは增大し, さらにその新鮮面にボン ディング剂を塗布すると追加レジンの接着強さは 若干增加していることがわかる。

次に, 実際に口内に 1 年間置かれたクリアフィ ル・ホステリアに追加充填した場合の成績 ${ }^{26}$ （四 15）をみてみよう。机処置では全く接着しなかっ たものが，カーハイドバーで古いレジン面を削 ると新しいレジンが接着するよらになり, さらに ボンディング処理を加えると $20 \%$ ばかり接着強さ が増大することが判明した。

では実際に古いレジン表面をどの程度まで除去 すればよいのかが問題となる。まだ実験の途中段 階ではあるが，そのレジン面を $200 \mu \mathrm{m}$ 以上削除 寸れば， $180 \mathrm{kgf} / \mathrm{cm}^{2}$ 程度の接着強さが得られる ことが確認されている。

かよらなことから，咬耗した古いレジンを補修 する場合には，污染面をカーバイドバーで 0.2 $0.3 \mathrm{~mm}$ 程度削除し，ボンディング剤を整布して 


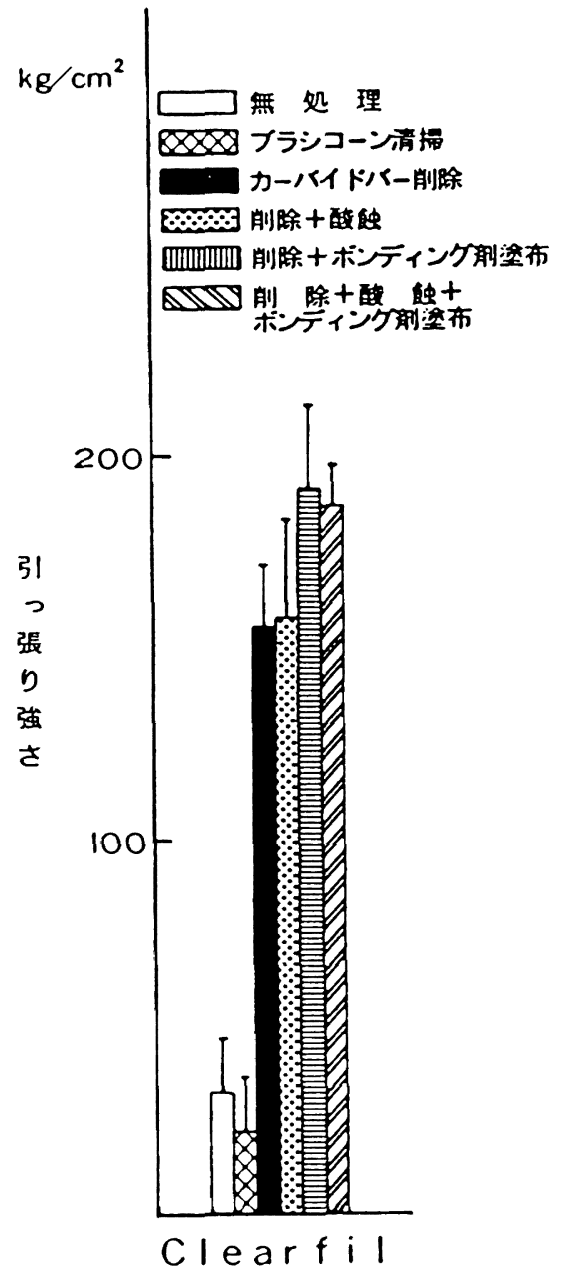

図14 3 力月後に追加充填したものの接着力

から新しいレジンを追加してやれば良い。しか し，一部に歯質の露出を伴う場合にはレジンとと もに歯質をも若干削除して, 酸エッチングを行っ てから，ボンディング剤を塗布してやれば追加レ ジンの予後は良好なものとなる。しかしながら， 補修追加充買はあくまでも便宜的なものなので, 優秀なレシンン材料の出現を期待したい。

\section{VI. おわりに}

臨床的に 2 年経過した臼歯コンポジットレジン 修復物の咬耗について観察し, 得ら机た所見から

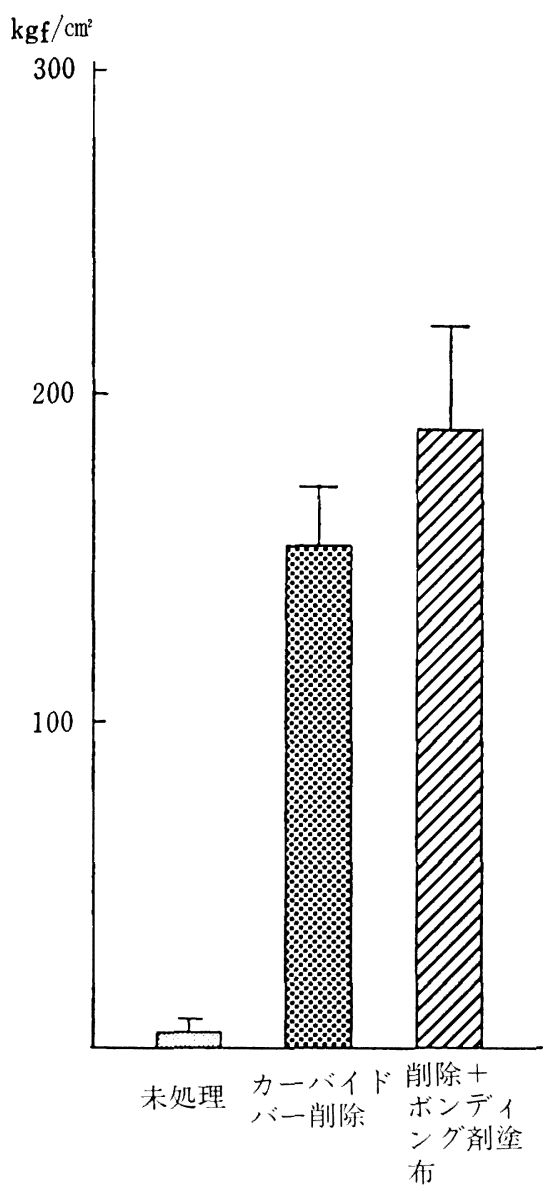

図151年後に追加充填された Clearfil Posterior の 接着强さ(削除は表層から $200 \mu \mathrm{m}$ )

その咬耗のメカニズムと咬耗対策について言及し た。

口内観察によって初めて歯牙修復材料の適正評 価が下されるが，特に耐咬磨耗性を調べるために は長期間を要し, 材料の開発改善の情報の入手が 遅れがちとなる。それゆえ, 短期的研究から咬耗 に関する長期予測を導き出す方法を是非とも案出 せ齐ばならない。いまだに理想的試験法がないの で, 今後, 臨床研究を重ねながら臨床に則した合 理的な咬磨耗試験法の実現に向かって努力してい きたいと思っている。 


\section{文献}

1) Bowen, R. L. : Development of a silicaresin direct filling material. US National Bureau of Standards 6333, 1958.

2) Phillips, R.W., Avery, D.R., Mehra, R., Swartz, M. L. and McCune, R. J. : One-year observations on a composite resin for class II restorations. J. Prosthet. Dent. 26 : 68-77, 1971.

3) Phillips, R.W., Avery, D. R., Mehra, R., Swartz, M. L. and McCune, R. J. : Observations on a composite resin for class II restorations : Twoyear report. J. Prosthet. Dent. 28 : 164-169, 1972.

4) Phillips, R.W., Avery, D.R., Mehra, R., Swartz, M. L. and McCune, R. J. : Observations on a composite resin for class II restorations: Three-year report. J. Prosthet. Dent, $30: 891-$ 897, 1973.

5) Leinfelder, K. F., Sluder, T. B., Sockwell, C. L., Strickland, W. D. and Wall, J. T. : Clinical evaluation of composite resins as anterior and posterior restorative materials. J. Prosthet, Dent. 33 : 407-416, 1975.

6) Leinfelder, K. F., Sluder, T. B., Santos, J. F. F. and Wall, J. T. : Five-year clinical evaluation of anterior restorations of composite resin. Oper. Dent. 5 : 57-65, 1980.

7) Eames, W. B., Strain, J. D., Weitman, R. T. and Williams, A. K. : Clinical comparison of composite, amalgam, and silicate restorations. J. A. D. A. $89: 1111-1117,1974$.

8) 藤井升次, 黑瀬信隆, 清水建彦, 福家 堯, 井 上正義，河見忠雄，小林久紀，牧野春三，中村 正幸, 安井健次郎：コンポジットレジン修復材 Addent 35, Addent 12の臨床成績について. 歯 科医学 $35: 565-574,1972$.

9）岩久正明：複合レジン充填の臨床成績について. 日歯保誌 $16: 282-288,1973$.

10) Silverstone, L. M. and Dogon, I. L. : The Acid Etch Technique. St. Paul, Minnesota, 1975, North Central Pub. Co., 93-159.

11）山内淳一, 增原英一, 中林宣男, 柴谷享一郎, 和田 徹 : 歯科用材料. 日公開特報 昭和53110637, 1978.

12）堀江恭一：日粜用コンポジットレジンの咬耗に 関する研究一第 1 報 咬耗量測定法について一. 口病誌 $51: 36-44,1984$.
13）坭江恭一：臼歯用コンポジットレジンの咬耗に 関する研究一第 2 報 臨床評価一. 口病誌 51 : 45-65, 1984.

14) Kusy, R. P. and Leinfelder, K. F. : Pattern of wear in posterior composite restorations. J. Dent. Res. 56 : 544, 1977.

15) Buonocore, M. G., Matsui, A. and Yamaki, M. : Abrasion of restorative materials. N. Y. State D. J. 32 : 395-400, 1966.

16) Powers, J. M., Allen, L. J. and Craig, R. G. : Two-body abrasion of commercial and experimental restorative and coating resins and amalgam. J. A. D. A. 89 : 1118-1122, 1974.

17）谷嘉明, 月星光博, 南部敏之, 井田一夫 : 超 微粒子フィラー配合コンポジットレジンの材料 学的性質. 歯材器誌 $37: 109-113,1980$.

18）小林泰子, 本村正子, 武谷道彦, 山本 泰, 的 野良次：コンポジットレジンの磨耗について, 2. マイクロフィラーレジンの歯ブラシによる磨 耗. 日米保誌 $24: 628-637,1981$.

19）平沢忠, 平野進, 平林茂, 原嶋郁郎, 奈 須郁代, 黑沢俊夫：ミクロフィラーコンポジッ トレジンの機械的性質. 歯理工誌 $22: 187-$ 195, 1981.

20) Lambrechts, P., Ameye, C. and Vanherle, G. : Conventional and microfilled composite resins. Part II : Chip fractures. J. Prosthet. Dent. 48 : 527-538, 1982.

21）石川明子：コンポジットレジンの重合收絔と組 成分析. 日歯保誌 28 巻 4 号 (1958)投稿予定.

22）細田裕康, 山田敏元, 猪越重久, 堀江恭一, 吉 川孝子, 金城直美, 金田園子：ペースト・ペー ストタイプコンポジットレジンの無気泡練和に ついて、日本雨科保存学会 1985年度春季学会 （第82回）発表予定.

23）細田裕康, 子田兒一, 福島正義, 鞍立尭則：象 牙質接着性レジンの象牙質表層部における様相 についてーそのタッグ形成とレジン窩洞に対す る一提案. 新潟齿学会誌 $9: 107-118,1979$.

24）細田裕康：接着性レジン充填のための窩洞形成. 日歯医師会誌 $35: 954-962 ， 1982$.

25）千葉一雄: 追加充填コンポジットレジンの接着 力. 口病誌 $49: 458-470,1982$.

26）千葉一雄, 奥谷撞一郎, 山田敏元, 細田裕康 : 田歯修復用コンポジットレジンの追加充填に関 寸る研究一充填後比較的短期の場合について一. 日㐘保誌 28 巻 3 号 (1985) 投稿中. 